\title{
Caracterização macro-e microscópica dos ovários do bagre amarelo, Cathorops spixii (Agassiz, 1829), durante o ciclo reprodutivo
}

\author{
(Macro- and microscopic characterization of yellow-catfish Cathorops spixii (Agassis, 1829) \\ ovaries during reproductive cycle)
}

\author{
Jodir Pereira da Silva ${ }^{1}$; Alfredo Martins Paiva Filho ${ }^{1} \&$ Norair Salviano dos Reis ${ }^{2}$ \\ ${ }^{1}$ Instituto Oceanográfico da Universidade de São Paulo \\ (Caixa Postal 66149, 05315-970, São Paulo, SP, Brasil) \\ ${ }^{2}$ Instituto de Biologia da Universidade Estadual de Campinas \\ Departamento de Histologia e Embriologia \\ (Caixa Postal 6109, 13081-970, Campinas, SP, Brasil)
}

- Abstract: This study is based on the analysis of macroscopic anatomy and histological structure of 452 ovaries from females of Cathorops spixii caught in the "Pai Matos" islands (Cananéia-Iguape lagoonal-estuarine region - 24'59'42"S 47 54'27'W), São Paulo, Brazil. Six phases of oocyte development are considered, based on cytological characteristics of the germinative cells during the maturation process, and seven ovarian maturity stages, determined by histological structure of ovaries and by the occurrence and relative frequency of the six oocyte phases: "A"(immature), "Bi"(initial maturation), "Bf'(advanced maturation), "Ci"(partially mature), "Cf'(mature), " $D$ "(spent) and " $R$ "(recuperation). The presence of a single patch of oocytes clustered during the spawn by an acellular adhesive substance, suggests total spawning, and the oocyte development is classified as synchronic in groups. The examined ovarian macroscopic anatomy and histological structure are characteristic of the cistovarian type.

- Resumo: Este estudo é baseado na análise da anatomia macroscópica e da estrutura histológica de 452 ovários de fêmeas de Cathorops spixii coletadas nas Ilhas Pai

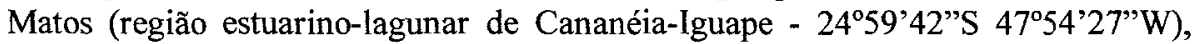
São Paulo, Brasil. Foram consideradas seis fases de desenvolvimento ovocitário, com base nas características citológicas das células germinativas durante o processo de maturação, e sete estádios de maturação ovarianos, determinados pela estrutura histológica dos ovários e pela ocorrência e frequiência relativa das seis fases ovocitárias: "A"(imaturo), "Bi" (em maturação inicial), "Bf'(em maturação final), "Ci"(parcialmente maduro), “Cf'(maduro), “D”(esvaziado) e "R"(em recuperação). A presença de apenas um lote ovocitário, unido durante a desova por uma substância adesiva acelular, sugere desova total, e o desenvolvimento ovocitário é classificado como sincrônico em grupos. A anatomia ovariana macroscópica e a estrutura histológica verificadas são características do tipo cistovariano.

- Descriptors: Marine catfish, Fish reproduction, Gonads, Histology, Cathorops spixii, Reproductive cycle.

- Descritores: Bagre marinho, Reprodução de peixes, Gônadas, Histologia, Cathorops spixii, Ciclo reprodutivo. 


\section{Introdução}

O bagre amarelo ou bagre-congo, como é conhecida popularmente a espécie Cathorops spixii, parece ser o bagre marinho mais comum do litoral brasileiro, ocorrendo em ambientes dulcícolas, marinhos e estuarinos, sendo nestes mais abundante (Yáñez-Arancibia \& Sanchez-Gil, 1988; Cervigón, 1966; Figueiredo \& Menezes, 1978).

Esta espécie é referida como de importância econômica por Cervigón (op. cit.), Amaral et al. (1988), Aguirre (1939) e Figueiredo \& Menezes (op. cit.).

A identificação, a caracterização e a freqüência das células germinativas nos diferentes estádios durante o ciclo reprodutivo, bem como o conhecimento da estrutura geral das gônadas, são fundamentais para a determinação do grau de desenvolvimento ovariano e o tipo de desova da espécie (Alexandrino et al., 1985 e Lima et al., 1991; Monteros \& Labarta, 1987).

Tais estudos sobre a biologia reprodutiva de peixes constituem a base para pesquisas sobre análises da atividade hormonal no processo reprodutivo e piscicultura, contribuindo, deste modo, para o desenvolvimento da administração pesqueira $\mathrm{e}$ preservação da espécie (Alexandrino et al., op. cit., Lima et al., 1991; Monteros \& Labarta, op. cit., Peres-Rios, 1995).

Inexistem até o momento trabalhos sobre a caracterização macro- e microscópica dos ovários de Cathorops spixii durante o ciclo reprodutivo.

Este trabalho tem por objetivo caracterizar macro- e microscopicamente a morfologia dos ovários de $C$. spixii, e descrever, através de estudo microscópico, o desenvolvimento dos tipos celulares germinativos ovarianos.

\section{Material e métodos}

Os ovários foram obtidos de 452 espécimes de Cathorops spixii, os quais foram coletados mensalmente entre janeiro de 1994 e janeiro de 1995 nas Ilhas Pai Matos (24'59'42"S 4754'27'W), região estuarino-lagunar de Cananéia-Iguape, no litoral sul do estado de São Paulo. Foram utilizadas redes de arrasto de portas do tipo "otter-trawl", com $12 \mathrm{~m}$ de boca, malhagem de $30 \mathrm{~mm}$ no corpo e manga e de $25 \mathrm{~mm}$ no sacador com portas pesando $40 \mathrm{~kg}$ cada, tendo sido operadas com o Barco de Pesquisas "Albacora" do Instituto Oceanográfico da Universidade de São Paulo, à velocidade de cerca de 2 nós e duração de 10 minutos.
Os peixes foram identificados com o auxílio da chave de identificação de Figueiredo \& Menezes (1978), pesados (peso total em g), medidos (comprimento total em $\mathrm{mm}$ ), e posteriormente submetidos a incisão ventro-longitudinal para que, após a retirada do trato digestivo, fossem fotografados os ovários ainda na cavidade abdominal, quando foram medidas suas dimensões de comprimento e largura $(\mathrm{mm})$ com auxílio de paquímetro. Após medidos, os ovários foram retirados da cavidade abdominal, pesados (g) e fixados por um período prévio de uma hora, sendo retirados posteriormente fragmentos de espessura menor que $5 \mathrm{~mm}$ das porções média, do quarto anterior e posterior dos ovários, os quais foram fixados em solução de formalina a $10 \%$ pelo tempo mínimo de 24 horas, sendo depois submetidos à inclusão e microtomia em parafina e às colorações rotineiras (hematoxilina-eosina e tricrômico de Masson), além de métodos histoquímicos (Método de Perls contracorado com solução aquosa de vermelho neutro a $10 \%$ e PAS contracorado com hematoxilina), para que se realizasse a observação à microscopia de luz. Nos ovários com ovócitos de maior diâmetro, fragmentos subseqüentes fixados foram submetidos à microtomia de cortes seriados, de modo a obter preparações permanentes dos ovários contendo diferentes porções do mesmo ovócito.

De acordo com a presença e freqüência (classificada como rara, pouco freqüente e muito freqüente) das diferentes fases de desenvolvimento das células germinativas ovarianas, descritas segundo o padrão de denominação sugerido por West (1990), e diagnosticados pela observação das preparações permanentes dos ovários, foi elaborada uma escala dos estádios de maturidade gonadal em 7 estádios: A (imaturo), Bi (em maturação inicial), Bf (em maturação final), $\mathrm{Ci}$ (parcialmente maduro, contendo alguns ovócitos prontos para serem desovados), Cf (totalmente maduro, contendo praticamente todos os ovócitos prontos para serem desovados), D (desovado) e R (em recuperação). Para cada estádio de maturidade gonadal foram efetuadas as descrições dos aspectos macro- e microscópicos, além de terem sido realizadas fotografias e fotomicrografias.

\section{Resultados}

\section{Anatomia macroscópica dos ovários}

Os ovários de Cathorops spixii compõem-se de estruturas pares, localizadas ventralmente aos rins, encontrando-se ligadas ao revestimento da parede dorsal do celoma através do mesovário. Cada ovário é uma estrutura alongada, de secção circular, 
com a extremidade anterior livre, e a extremidade posterior ou caudal contínua com o oviduto. Ambos ovidutos fundem-se em um ducto comum, abrindo-se para o meio externo pelo poro genital.

O tamanho, forma, coloração e a vascularização dos ovários sofrem modificações de acordo com o grau de desenvolvimento gonadal e as variações destas características possibilitaram a elaboração da escala de maturação gonadal proposta.

\section{Análises microscópicas do ovário}

\section{Organização estrutural}

O ovário apresenta sua parede composta por três camadas distintas, denominadas túnicas (Fig. 1). A camada externa é a túnica serosa, que é composta por tecido conjuntivo fibroso coberto por mesotélio, caracterizado por apresentar-se como um tecido epitelial pavimentoso simples, apresentando-se contínuo com o tecido epitelial pavimentoso simples do mesovário. $O$ tecido conjuntivo da túnica serosa é contínuo com o tecido conjuntivo do mesovário $\mathrm{e}$ com $\mathrm{o}$ da túnica subjacente, denominada albugínea.

A túnica albugínea é a que se apresenta mais desenvolvida na parede do ovário, apresentando grande quantidade de feixes de fibras musculares lisas dispostas em várias camadas que se alternam nos planos longitudinal e transversal. Entre as camadas de músculo liso ocorre tecido conjuntivo frouxo, apresentando diferentes graus de vascularização, variando de acordo com o estádio de maturidade e com a localização, uma vez que a vascularização parece ser mais intensa na porção interna desta camada.

A túnica mais interna da parede ovariana constitui-se de epitélio variando de cúbico simples a pavimentoso simples apoiado sobre uma fina camada de tecido conjuntivo frouxo, contínuo com o da túnica albugínea.

Da túnica ovariana interna projetam-se, nos ovários em estádios iniciais de desenvolvimento, septos que originam as lamelas em direção ao lúmen do ovário (Fig. 2). Tais estruturas variam em tamanho e podem apresentar ramificações (Fig. 2). Nas lamelas encontram-se ovócitos em diferentes estágios de desenvolvimento, circundados por envoltórios celulares que formam os folículos, estando estes também envoltos por tecido conjuntivo contínuo com o das lamelas ovarianas.
Fases de desenvolvimento das células germinativas ovarianas:

Ovogônias - São originadas ao longo da vida, ocorrendo isoladamente ou em grupos ("ninhos") associados ao revestimento do lúmen ovariano (Fig. 3A). São as menores células da linhagem germinativa ovariana, apresentando citoplasma escasso pouco corado ou moderadamente basófilo, núcleo grande e central, com cromatina dispersa e nucléolo central. Geralmente não são observadas células pré-foliculares ao redor da ovogônia.

\section{Ovócitos avitelogênicos:}

Ovócitos em estádio cromatina-nucleolar São encontrados próximo às ovogônias, a partir das quais são originados, após a fase de proliferação e envolvimento por células pré-foliculares. Possuem, aparentemente, tamanho semelhante ao das ovogônias e aparecem grupadas em "ninhos" de folículos primordiais junto ao epitélio de revestimento do lúmen ovariano. Tais folículos contém ovócitos exibindo citoplasma escasso claro e moderadamente basófilo, núcleo grande, pouco corado, com nucléolo central associado a feixes de material cromatínico em disposição radial (Fig. 3B).

\section{Ovócitos perinucleolares:}

Iniciais - São células germinativas com volume aumentado em relação à fase anterior, possuindo formas poliédricas, citoplasma fortemente basófilo, núcleo volumoso e central, onde se encontram, em localização periférica, múltiplos nucléolos pequenos, arredondados e justapostos à carioteca (Fig. 4). $\mathrm{O}$ ovócito nesta fase de desenvolvimento encontra-se envolvido por uma camada única de células foliculares pavimentosas.

Tardios - No período tardio os ovócitos passam a apresentar citoplasma menos basófile, com presença de uma inclusão geralmente próxima ao núcleo, o núcleo de vitelo ou corpo de Balbiani (Fig. 5). No núcleo aumentado e basófilo a disposição periférica dos nucléolos é mantida, os quais podem possuir tamanhos variados e forma ovalada ou esférica. Cabe ressaltar, nesta fase, para fins de diagnóstico, a presença de uma ou duas camadas de células foliculares pavimentosas em torno do ovócito. 


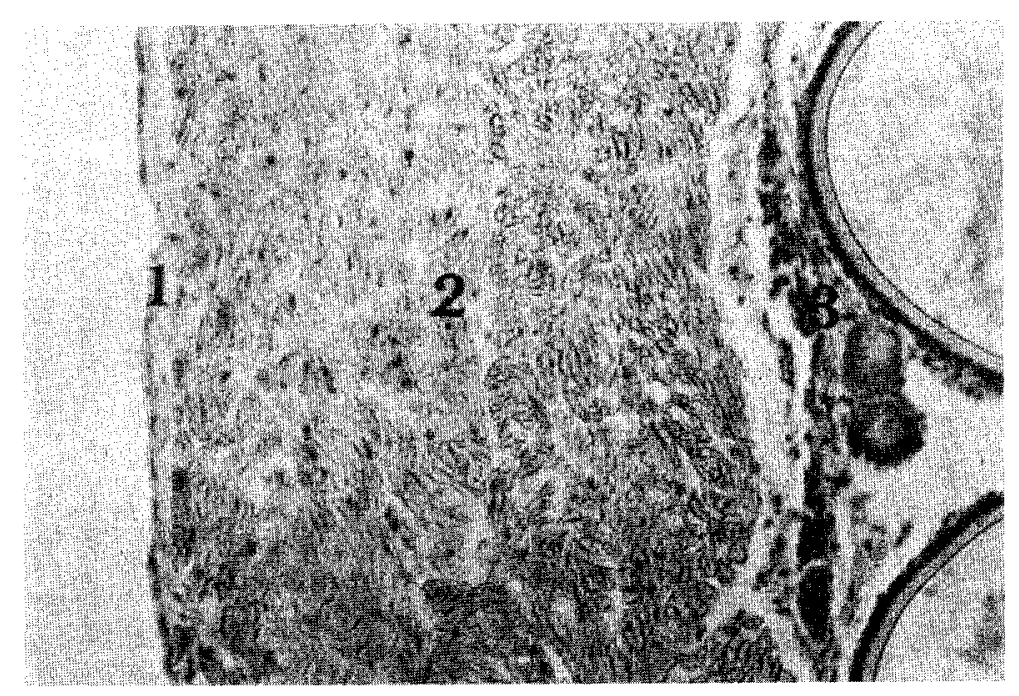

Fig. 1. Corte transversal do ovário de Cathorops spixii, evidenciando a parede ovariana. 1 . Túnica serosa; 2. Túnica albugínea; 3. Túnica interna. Tricrômico de Masson. 100X.

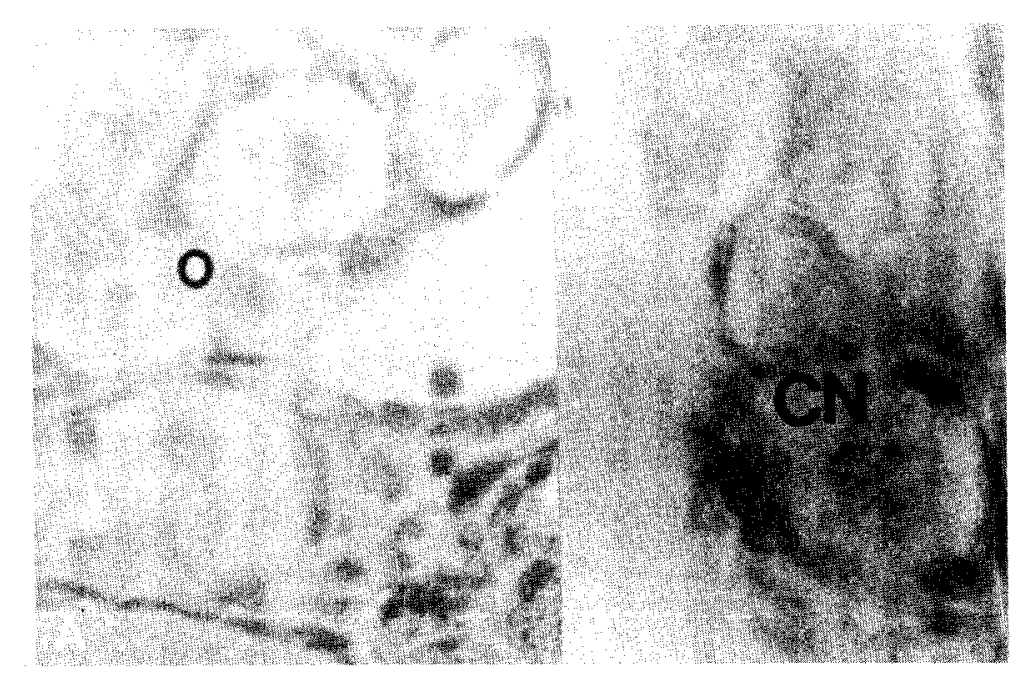

Fig. 3. Cortes transversais dos ovários de $C$. spixii. A. Ovogônias em grupos $(\mathrm{O})$. HE $1280 X$. B. Ovócito em estádio cromatina-nucleolar (CN). HE. 1440X.

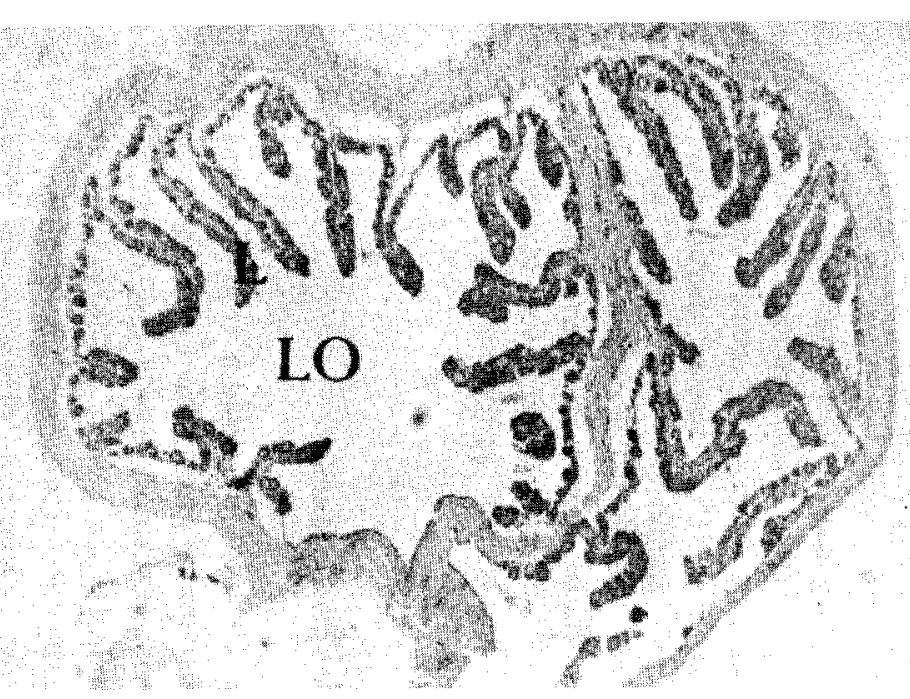

Fig. 2. Corte transversal dos ovários de $C$. spixii, evidenciando a presença de lamelas ovarianas (L) projetadas em direção ao lúmen ovariano (LO). HE. 20X.

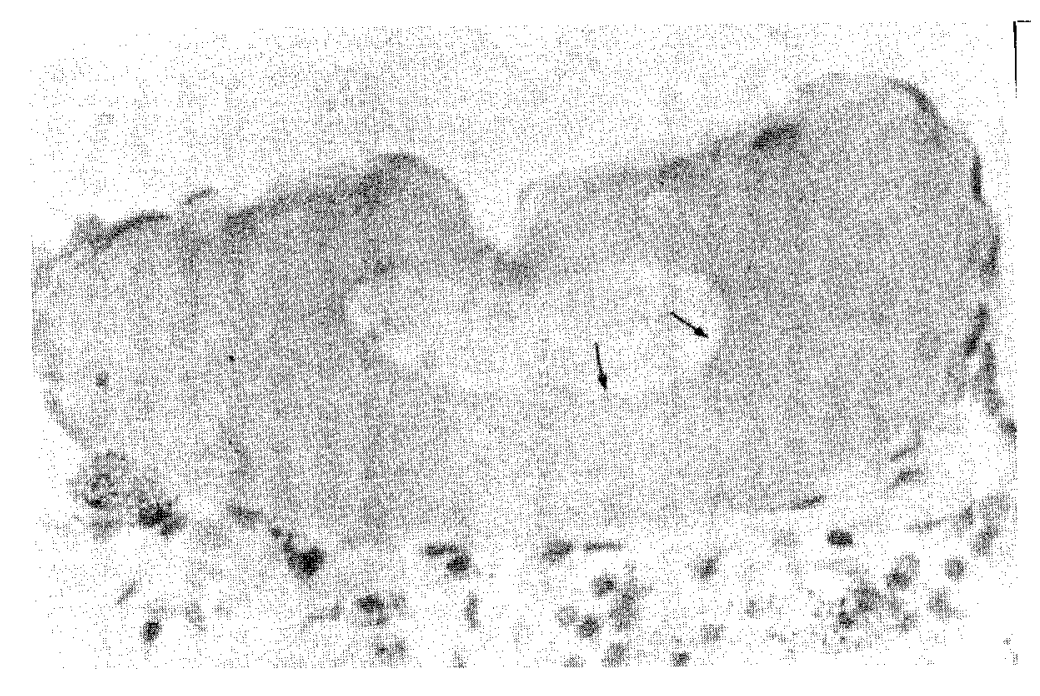

Fig. 4. Corte transversal de ovário de C. spixii. Ovócito em estádio perinucleolar inicial com vários nucléolos dispostos na porção periférica do núcleo (setas). Nota-se a presença de camada única de células foliculares pavimentosas. HE. 960X. 


\section{Ovócitos em vitelogênese:}

Ovócitos em estádio cortical-alveolar:

Iniciais - Este período caracteriza-se pela formação de alvéolos citoplasmáticos corticais, que não se apresentaram corados nas técnicas de coloração utilizadas neste trabalho (Fig. 6A). Além da presença dos alvéolos corticais, o ovócito corticalalveolar inicial apresenta núcleo fracamente corado contendo os nuclélos periféricos basófilos. Nesta fase de desenvolvimento ovocitário geralmente não se verifica a presença dos corpos de Balbiani e as células foliculares que envolvem 0 ovócito apresentam-se em dupla camada, inicialmente pavimentosas $\mathrm{e}$, tardiamente, a camada pavimentosa em contato com o ovócito tendem à forma cúbica. Entre o ovócito e as células foliculares inicia-se a formação de uma camada acelular eosinófila (Fig. 6B) e PAS positiva acumulada inicialmente em pontos isolados - a membrana vitelina.

Tardios - O citoplasma moderadamente acidófilo é totalmente ocupado na sua periferia por alvéolos aumentados em número e tamanho, conferindo-lhe aspecto reticulado ou alveolado (Fig. 7A). A membrana vitelina torna-se mais espessa e, portanto, evidente, enquanto que $o$ envoltório folicular apresenta uma camada de células cúbicas envolvidas por células pavimentosas (Fig. 7B). No ovócito cortical-alveolar tardio é possivel observar a presença da teca com vasos sangüíneos de pequeno calibre.

Ovócitos vitelogênicos - Após a formação dos alvéolos corticais, ocorre a formação de glóbulos de vitelo, que ocupam, na fase inicial, a porçåo central da célula. Devido à intensificação da vitelogênese, o ovócito apresenta volume citoplasmático aumentado. Não foi verificada a presença do núcleo em ovócitos nesta fase nos cortes examinados. A membrana vitelina passa a apresentar estriaçðes transversais devido à formação de microvilos, projetados da membrana plasmática do ovócito (Fig. 8). As células foliculares alteram-se morfologicamente, tornando-se colunares e apresentando basofilia basal, citoplasma com vesículas moderadamente basófilas e PAS positivas. A teca apresenta-se com vasos sanguíneos de pequeno a médio calibre, maiores do que na fase anteriormente descrita.

Ovócitos em maturaçăo final - Os ovócitos nesta fase caracterizam-se pelo aumento acentuado do volume citoplasmático, resultante do preenchimento de todo o citoplasma por glóbulos de vitelo que, após fusionarem-se, formam uma massa contínua de vitelo. A membrana vitelina espessa apresenta estriações transversais marcantes, devido à ocupação por microvilos relativamente grandes e numerosos, e que, por isso, representam importante fator de diagnóstico desta fase de desenvolvimento ovocitário (Fig. 9). Em contato com os microvilos desta membrana ocorrem as células foliculares colunares que mantém as características de células em ativa síntese proteica, envolvidas pela teca ricamente vascularizada, contendo vasos de grande calibre.

Ovócitos atrésicos - São ovócitos caracterizados pela intensa desorganização celular (Fig. 10). Pode haver enrugamento e distorção do folículo, dobra e quebra da membrana vitelina, desorganização do vitelo e citoplasma e liquefação dos grânulos vitelínicos, infiltração de células da teca e sangue. A membrana vitelina mantém-se íntegra morfologicamente durante absorção dos ovócitos atrésicos, sendo uma das últimas estruturas a serem degradadas no folículo. Após a degradação do ovócito e do foliculo que o contém, ocorre a absorção destes por macrófagos, que podem ser diagnosticados pela presença em seu citoplasma de pigmentos hemossideróticos resultantes da fagocitose de eritrócitos e resíduos eritrocitários. Tais pigmentos são facilmente diagnosticados pela reação de Perls, onde os pigmentos hemossideróticos são corados em azul e o restante das estruturas celulares em vermelho (Fig. 11). Uma vez completa a absorção do folículo contendo o ovócito atrésico, inicia-se o preenchimento deste por fibras colágenas, formando uma estrutura denominada como corpo residual, que origina nódulos fibrosos (Fig. 12).

Embora a atresia possa ocorrer em praticamente todos os estádios de desenvolvimento dos ovócitos, este processo parece ser mais comum nos ovócitos vitelogênicos nesta espécie.

Folículos pós-ovulatórios - Após a maturação final dos ovócitos, ocorre a expulsão dos mesmos dos folículos, originando os folículos pósovulatórios (Fig. 13). Estes folículos desenvolvem-se, originando estruturas algumas vezes denominadas como corpos lúteos pós-ovulatórios (Fig. 14). Nestes, as células foliculares sofrem hipertrofia e aparentemente assumem funçáo na absorção e na produção de hormônios.

Da mesma maneira que nos ovócitos atrésicos, nos folículos pós-ovulatórios ocorre infiltração de sangue, posteriormente absorvido pelas células foliculares e por macrófagos.

Após a absorção no interior do folículo, este é preenchido por fibras colágenas, formando nódulos fibrosos (referidos, às vezes, na literatura especializada, como corpo albicans) semelhantes aos ocorrentes após absorção de ovócitos atrésicos (Fig. 15). 


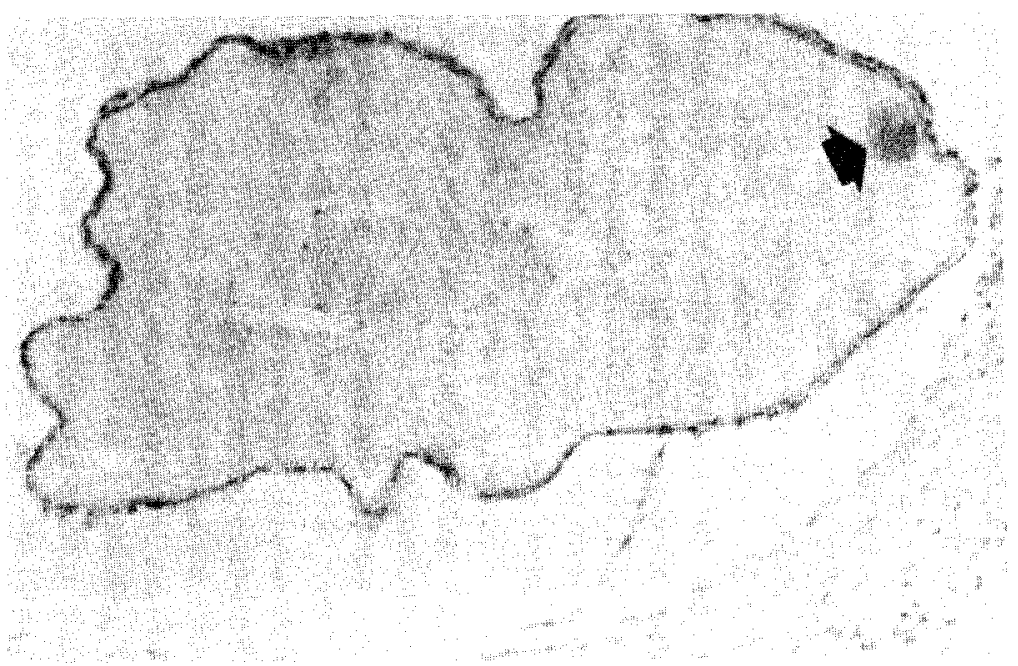

Fig. 5. Corte transversal de ovário de C. spixii. Ovócito em estádio perinucleolar tardio com nucléolos na periferia do núcleo e corpo de Balbiani (seta). Nota-se a presença de duas camadas de células foliculares pavimentosas envolvendo o ovócito. HE. $240 \mathrm{X}$.

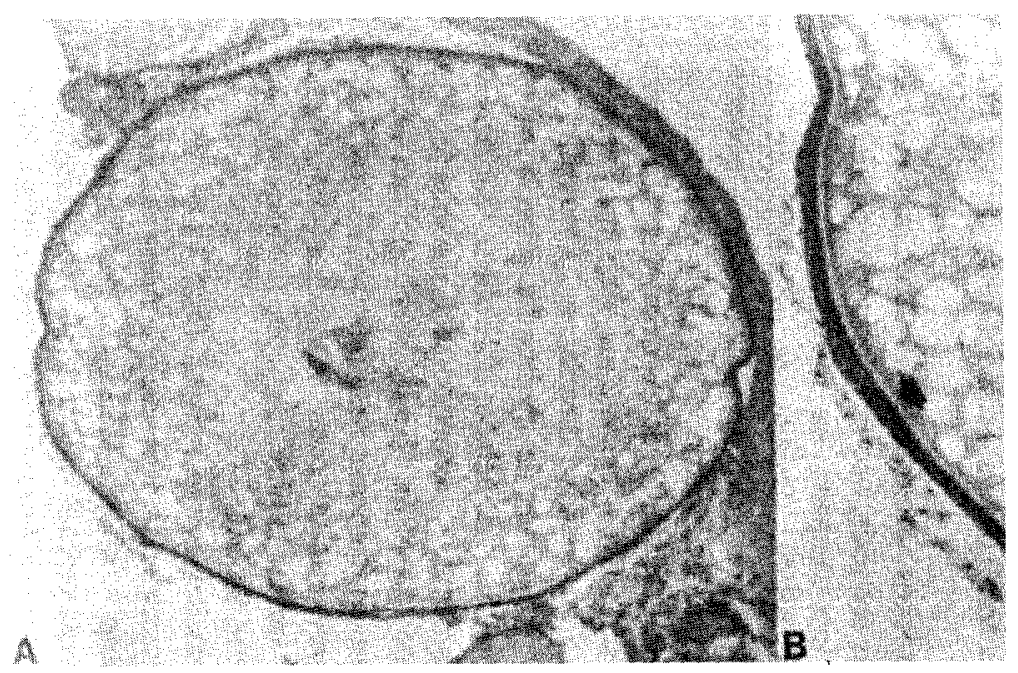

Fig. 7. Corte transversal de ovário de C. spixii. A. Ovócito em estádio cortical-alveolar tardio com o ovoplasma apresentando aspecto alveolado. HE.100X. B. Detalhe evidenciando a presença da membrana vitelina mais espessa, entre as células foliculares e o ovócito. HE. $240 \mathrm{X}$

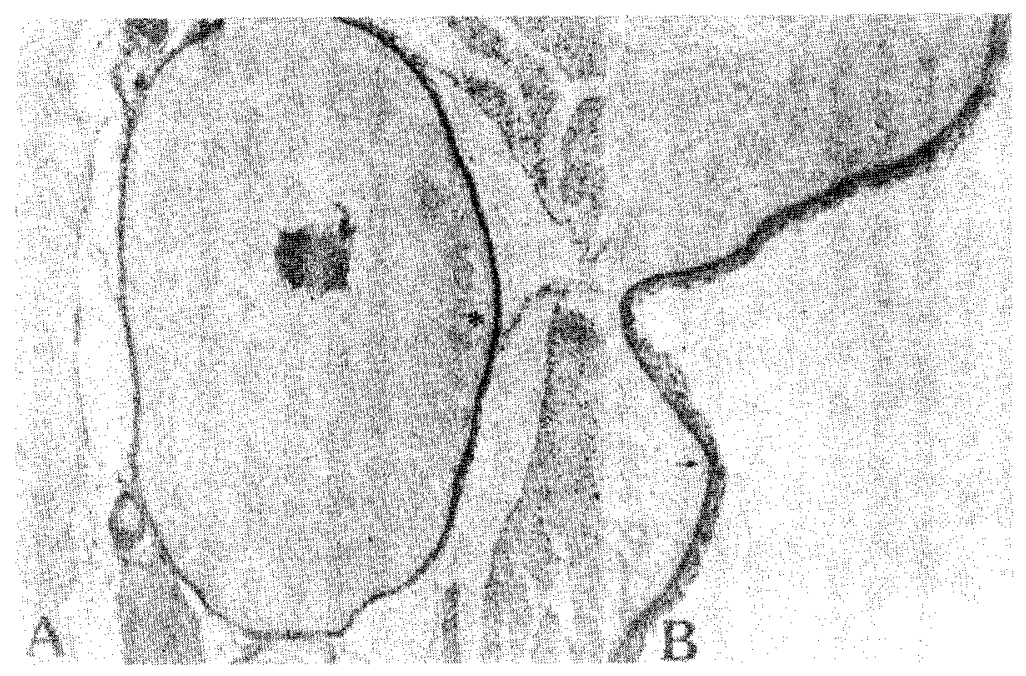

Fig. 6. Corte transversal de ovário de C. spixii. A. Ovócito em estádio cortical-alveolar inicial contendo os alvéolos corticais na periferia do ovoplasma (*). HE. 100X. B Detalhe da formação da membrana vitelina (seta) disposta entre as células foliculares cúbicas e o ovócito. HE. $240 \mathrm{X}$

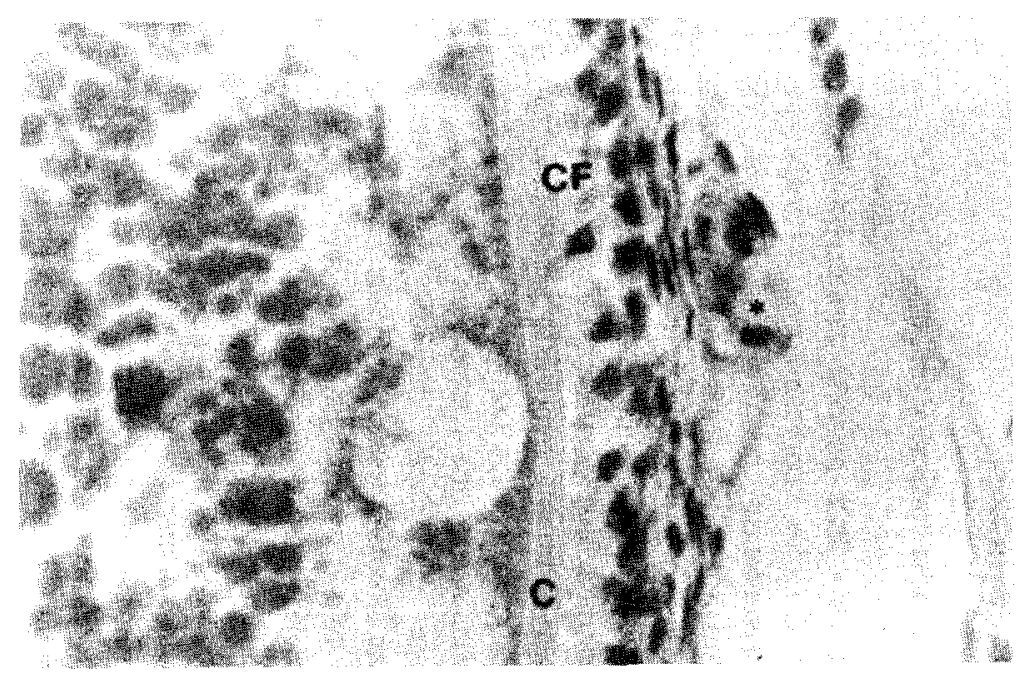

Fig. 8. Ovócito em estado vitelogênico, no qual se verifica a presença da membrana vitelina (C ) mais espessa, com e striação transversal devida à formação de microvilos. As células foliculares (CF) possuem forma colunar, ao redor das quais a teca apresenta-se mais vascularizada (*). HE. $640 \mathrm{X}$ 


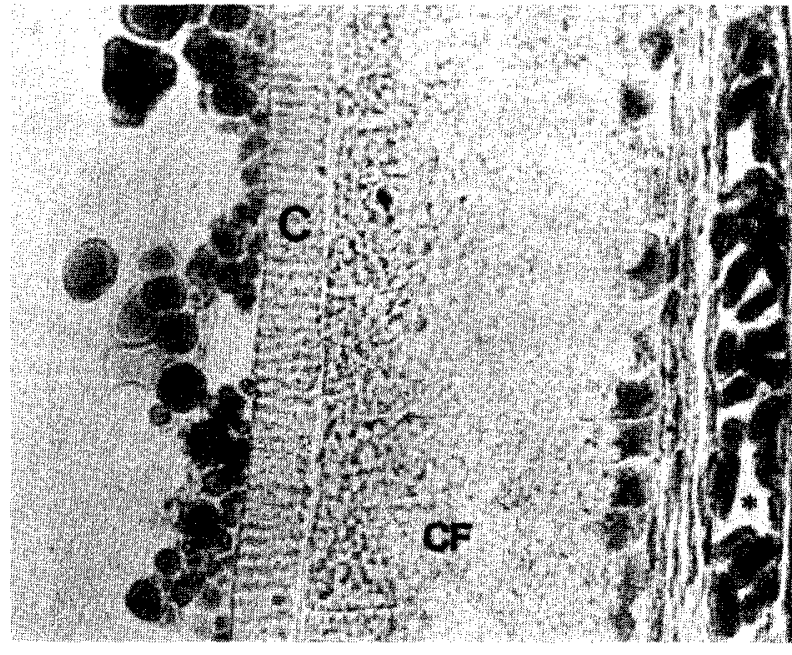

Fig 9. Ovócito em maturação final, com a presença de membrana vitelina (C) ainda mais espessa e estriaçăa transversal marcante devida à presença de microvilos relativamente grandes e numerosos. Células foliculares (CF) colunares e vascularizaçăo acentuada $(*)$. TM. $960 \mathrm{X}$.

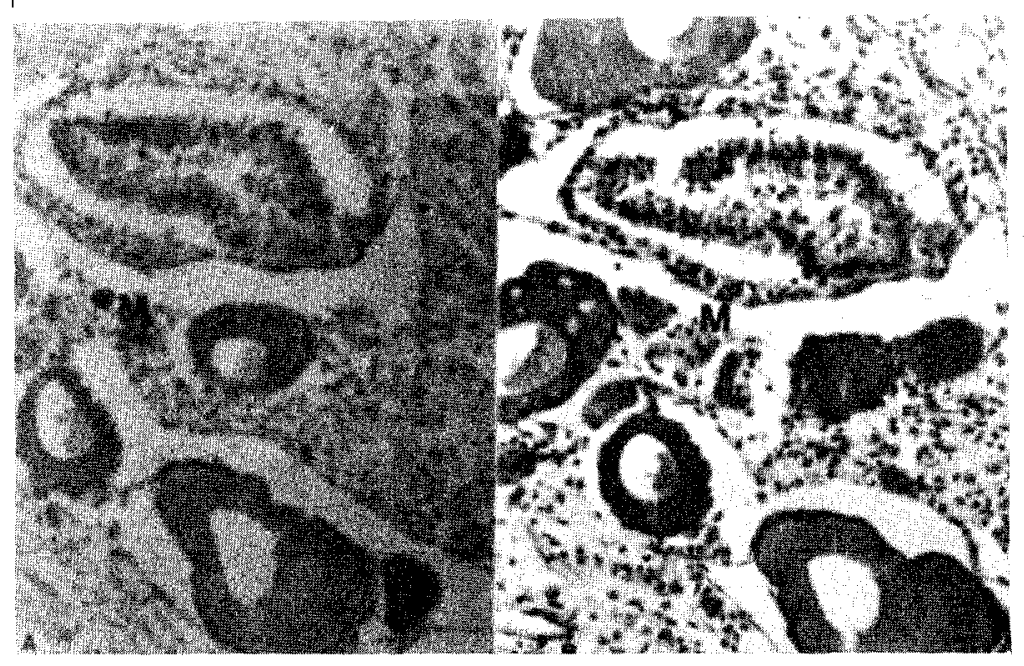

Fig. 11. Cortes transversais de uma mesma regiảo do ovário de $C$. spixii. A. Macrófagos (M) contendo pigmentos hemossideróticos. Reaçăo de Perls. B. Macrófagos (M) contendo pigmentos hemossideróticos. HE. 385X.

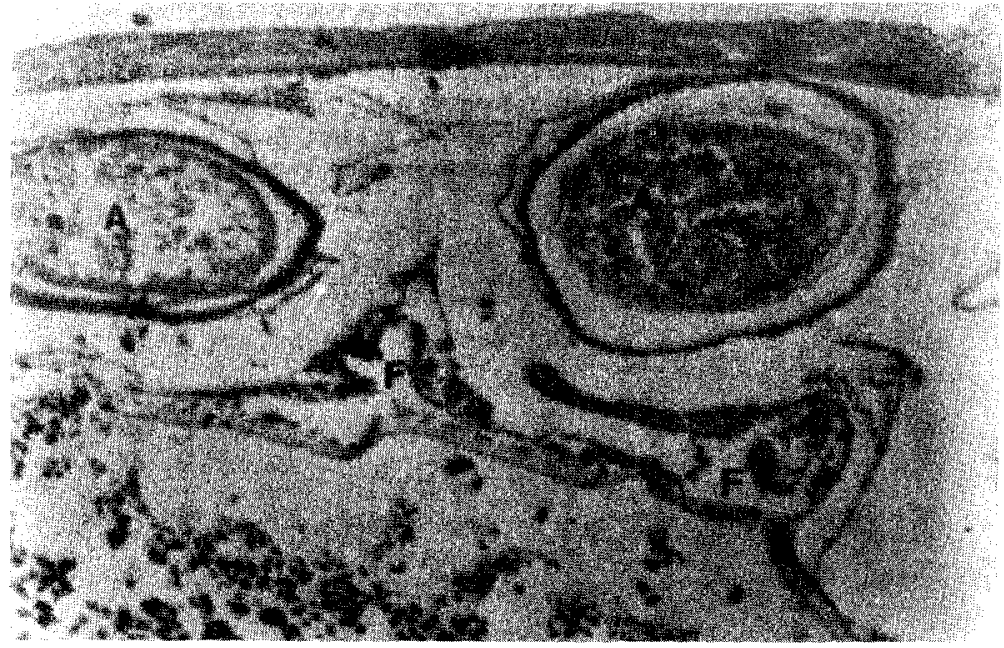

Fig. 10. Corte transversal do ovário de C. spixii. Eliminação de ovócito em maturaçăo final, evidenciando o início da formação do folículo pós-ovulatório $(F)$ e a presença de ovócitos atrésicos (A). HE. $25 \mathrm{X}$

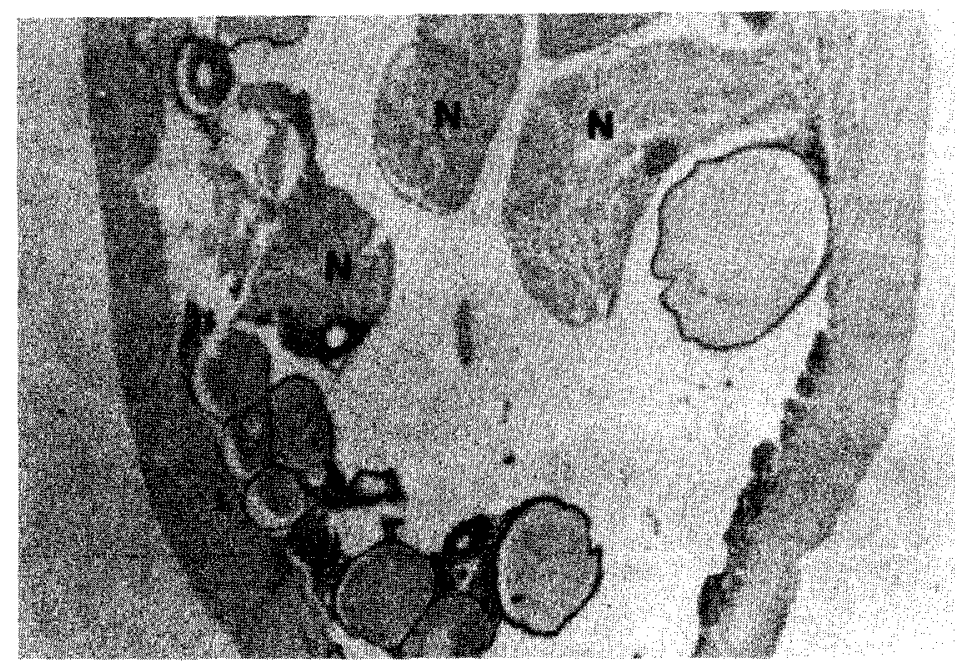

Fig. 12.Corte transversal do ovário de C. spixiii, Nódulos fibrosos (N). HE. 20X. 


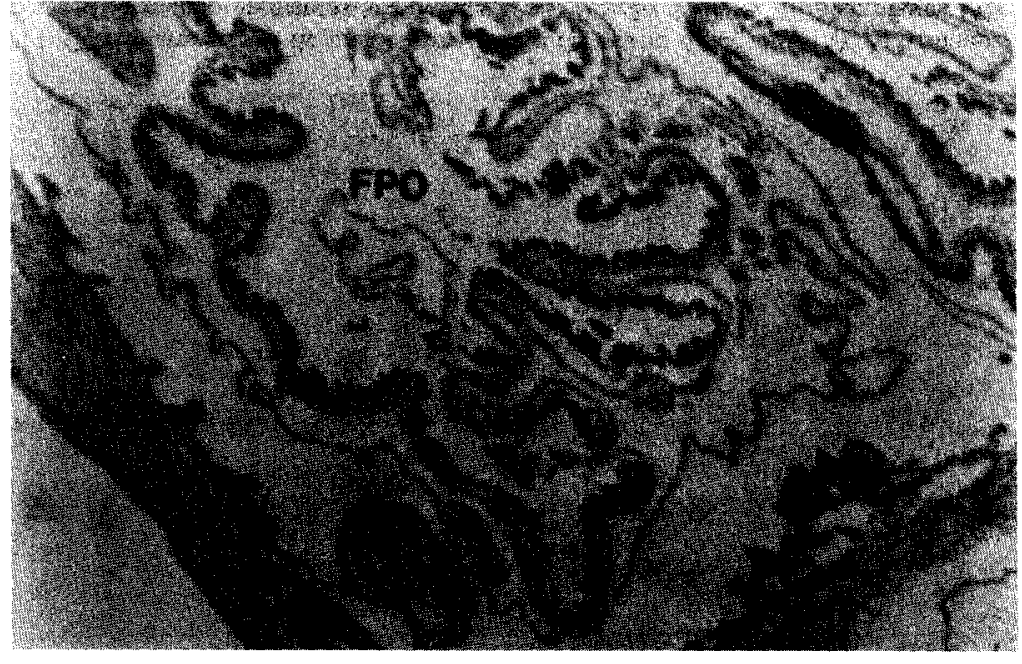

Fig. 13. Corte transversal do ovário de C. spixii. Folículo pós-ovulatório (FPO). HE. 25X.

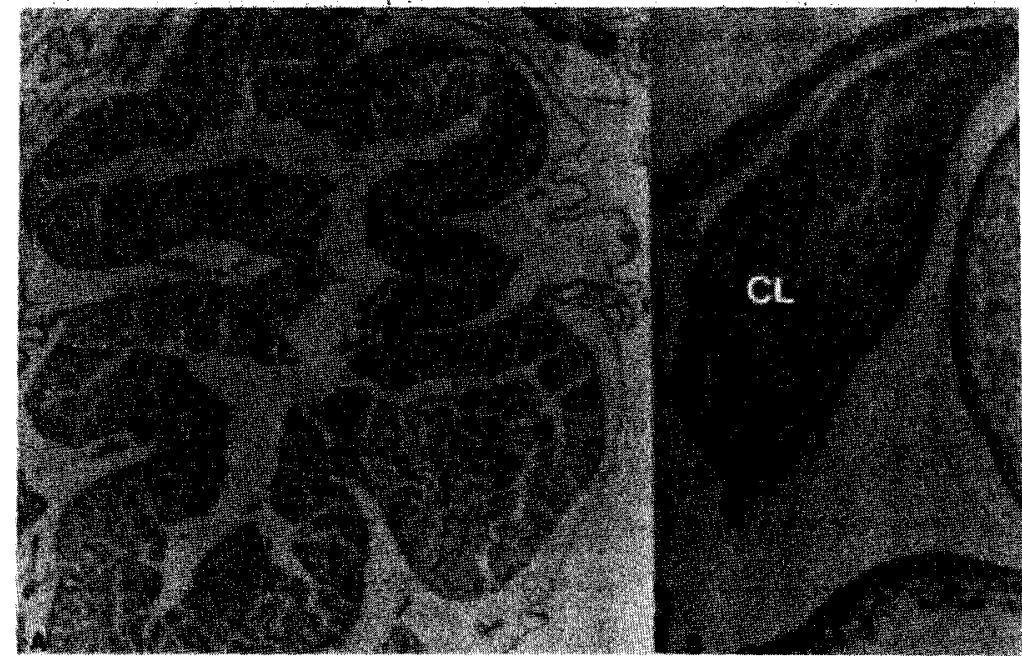

Fig. 14. Cortes transversais de ovários de $C$. spixii. A. Corpo lúteo (CL). HE. 20X. B. Corpo lúteo (CL) em processo de regressão. HE. $25 \mathrm{X}$.

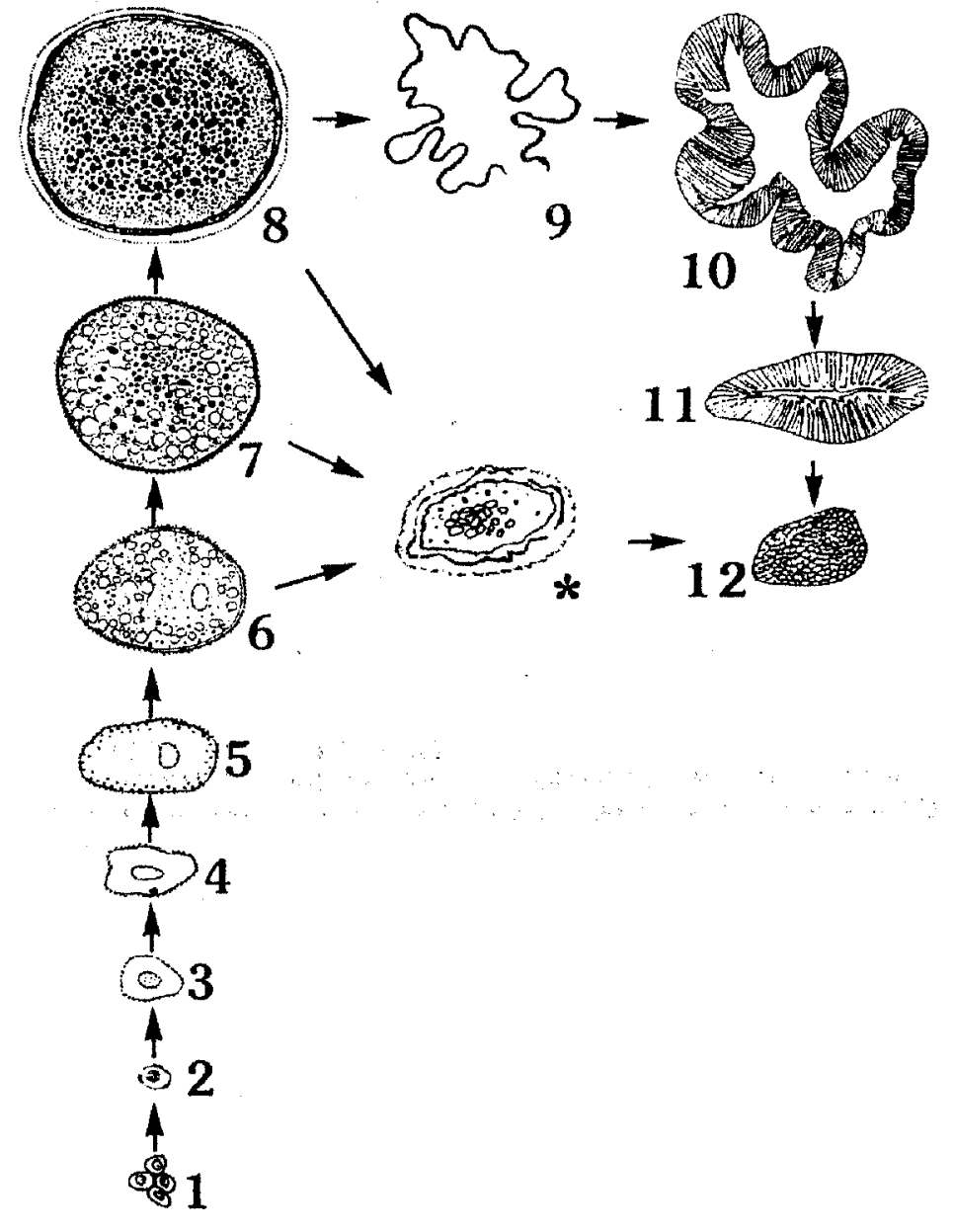

Fig. 15. Esquema do ciclo de desenvolvimento dos tipos celulares germinativos ovarianos de C. spixii. Ovogônias (1), ovócito em estádio cromatina-nucleolar (2), ovócitos perinucleolares inicial (3) e tardio (4), ovócitos em estádio cortical- alveolar inicial (5) e tardio (6), ovócito vitelogênico (7) e em maturação final (8), foliculo pós-ovulatório (9), corpo lúteo recém formado (10) e em regressão (11), nódulo fibroso (12) e ovócito atrésico $\left(^{*}\right)$. Não foram respeitadas as proporç̋̃es das dimensões entre os diferentes tipos celulares. 
A seqüência de desenvolvimento dos diversos tipos celulares germinativos ovarianos acima descrito encontra-se ilustrada na Figura 15.

\section{Escala de maturidade dos ovários:}

A partir do diagnóstico da presença e frequência dos tipos germinativos ovarianos, associado à descrição da estrutura dos ovários, determinaram-se sete estádios de desenvolvimento ovariano, dos quais também encontram-se descritas a seguir as características observadas macroscopicamente:

Estádio A (imaturo): Os ovários recém diferenciados ocupam menos de um terço da cavidade corporal, apresentam coloração branca a rósea e forma alongada, de secção circular a ovóide (Fig. 16). Macroscopicamente não se visualizam os ovócitos em desenvolvimento.

Microscopicamente observa-se fina parede ovariana, da qual projetam-se para o lúmen ovariano muitas lamelas ovarianas, nas quais verifica-se a presença de ovogônias e ovócitos em estágio cromatina-nucleolar pouco frequientes e ovócitos perinucleolares iniciais e tardios muito frequentes (Tab. 1).

Estádio Bi (em maturação inicial): Neste estádio os ovários mantém o tamanho pequeno, a coloração e a forma descritos no ovário imaturo (Fig. 17). Contudo, nos ovários em maturação inicial já é possivel a visualização, a nível macroscópico, dos ovócitos em desenvolvimento.

A nível de microscopia de luz, verifica-se menor frequêencia de lamelas ovarianas, contendo raras ovogônias e ovócitos em estádio cromatinanucleolar, ovócitos perinucleolares iniciais e tardios pouco freqüentes e ovócitos em estágio corticalalveolar inicial muito freqüentes (Tab. 1).

Estádio Bf (em maturação final): $\mathrm{Na}$ maturação final os ovários apresentam aumento em volume, que passam a ocupar pouco menos da metade do comprimento da cavidade corporal, possuem coloração branco-amarelada, com pontuações de coloração castanha, sendo mais evidente macroscopicamente a presença dos ovócitos em desenvolvimento (Fig. 18).

A observação microscópica dos ovários em maturação final possibilita a visualização da parede ovariana em início de vascularização e ligeiramente espessada em relação ao estádio anterior aonde evidencia-se a presença, junto dos ovócitos em desenvolvimento, de agrupamentos de macrófagos contendo no seu interior pigmento hemossiderótico de coloração castanha, diagnosticados pela reação histoquímica de Perls. Nesta fase do desenvolvimento ovariano verifica-se a presença de raras ovogônias e ovócitos em estádio cromatina-nucleolar, ovócitos perinucleolares iniciais, tardios e ovócitos em estádio cortical-alveolar iniciais pouco freqüentes e ovócitos em estádio cortical-alveolar tardios muito frequentes (Tab. 1).

Estádio Ci (parcialmente maduro, com alguns ovócitos prontos a serem desovados): Nesta fase de desenvolvimento, o ovário, mais volumoso, já ocupa mais da metade do comprimento da cavidade corporal $\mathrm{e}$ as suas paredes tornam-se translúcidas (Fig. 19).

A microscopia torna evidente o aumento da vascularização da porção interna da parede ovariana, bem como a diminuição da espessura desta. Além de raras ovogônias e ovócitos em estádio cromatina nucleolar e ovócitos perinucleolares e em estádio cortical-alveolar pouco freqüentes, observa-se a presença de ovócitos vitelogênicos muito freqüentes e raros ovócitos em maturação final (Tab. 1).

Estádio Cf (maduro, com praticamente todos os ovócitos prontos para a desova): $O$ ovário neste estádio passa a ocupar mais de dois terços da cavidade corporal, apresentando seu maior volume, devido a presença de ovócitos muito grandes, que são facilmente visualizados, graças à transparência da parede ovariana. Com isso, o ovário, translúcido, passa a ter coloração amarelada, característica devido à presença dos ovócitos contendo abundante quantidade de vitelo no seu interior (Fig. 20). Tais ovócitos às vezes apresentam-se unidos por uma substância adesiva, de coloração esbranquiçada, visível a olho nú.

Microscopicamente, a fina parede ovariana apresenta intensa vascularização na túnica interna. Tais vasos sangüineos ramificam-se, irrigando a região da teca dos ovócitos nos estádios finais de desenvolvimento. A presença muito frequente de ovócitos em maturação final é característica desta fase, embora ainda sejam encontrados ovocitos vitelogênicos pouco frequientes e os demais tipos germinativos ovarianos com ocorrência rara. Entre os ovócitos em maturação final evidencia-se, às vezes, a presença da substância que os mantém unidos, eosinófila, acelular e PAS positiva (Fig. $21 \mathrm{e}$ Tab. 1).

Estádio D (desovado): Os ovários apresentam-se completamente esvaziados, com coloração rósea e aparência flácida e hemorrágica (Fig. 22). A análise microscópica dos ovários desovados mostra a presença de folículos pósovulatórios muito freqüentes, que caracterizam esta fase do ciclo ovariano, ovócitos atrésicos pouco freqüentes e ovogônias, ovócitos em estádio cromatina-nucleolar e ovócitos perinucleolares raros. 


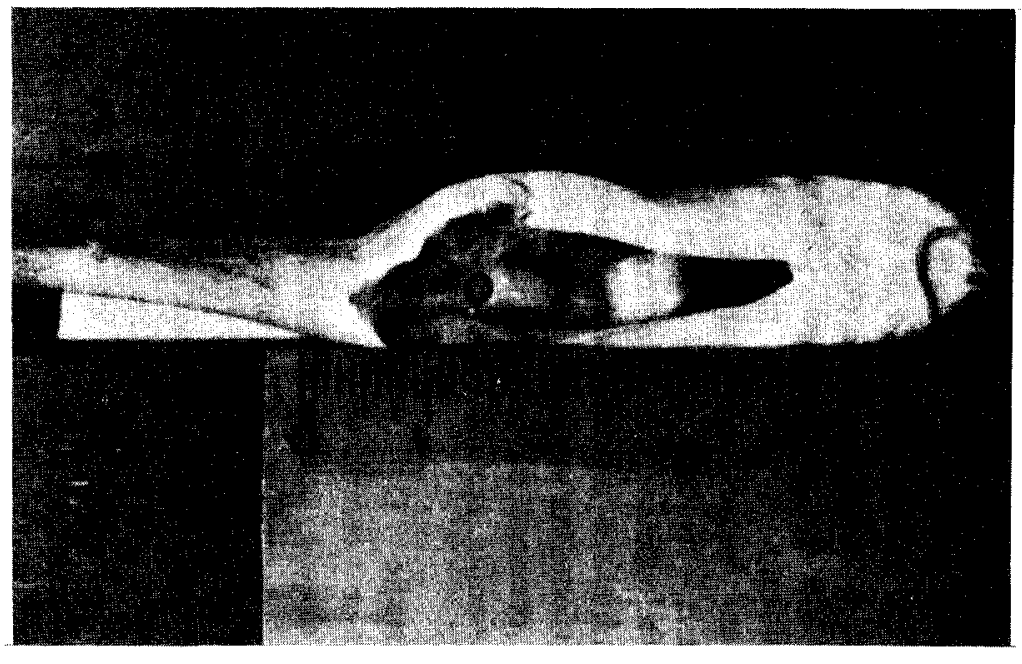

Fig. 16. Fêmea de $C$. spixii eviscerada com ovários imaturos $(O)$ dispostos ventralmente aos rins $(\mathrm{R})$. Escala em centímetros.

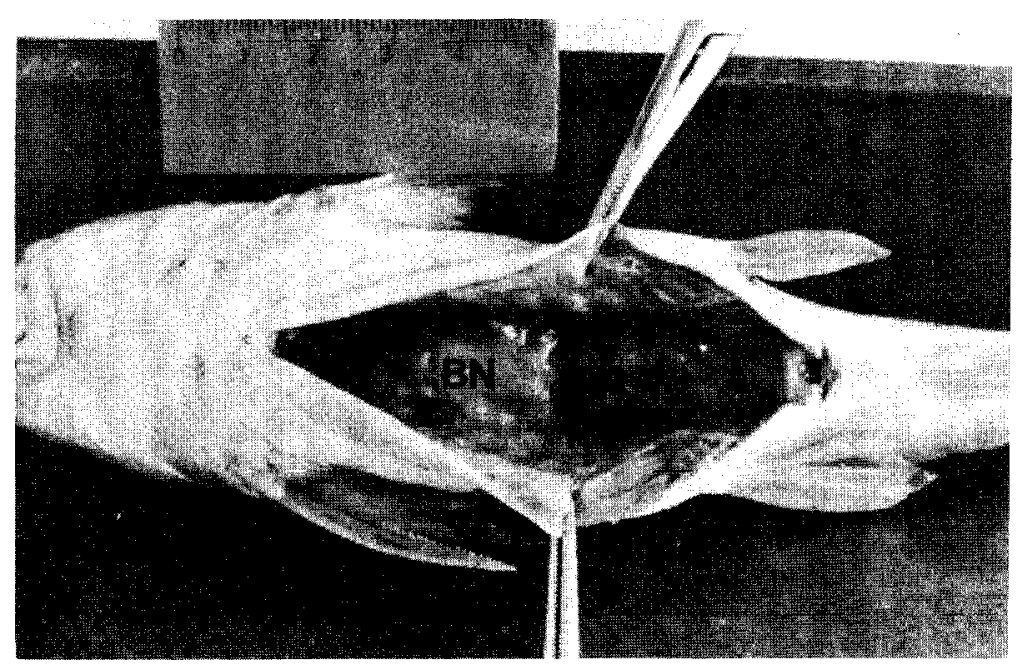

Fig. 18. Fêmea de C. spixii eviscerada com ovários em maturaçăo final $(O)$ dispostos ventralmente aos rins $(\mathrm{R})$ e bexiga natatória $(\mathrm{BN})$. Notar a presença mais evidente de ovócitos em desenvolvimento diagnosticados macroscopicamente, bem como de pontuaçðes de coloração castanha (seta). Escala em centímetros.

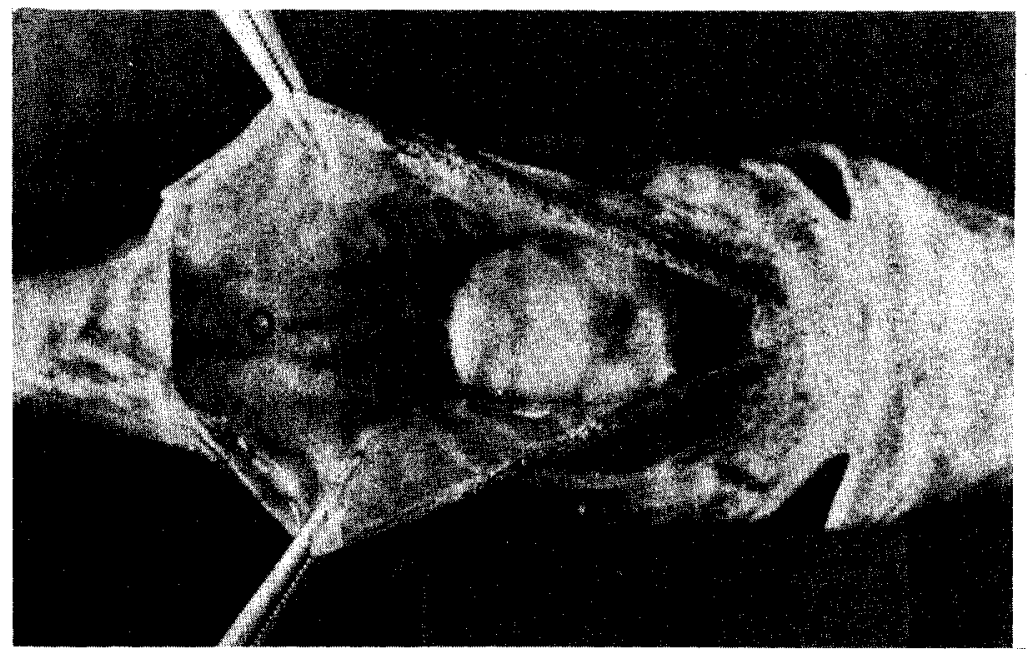

Fig. 17. Fêmea de C. spixii eviscerada com ovários em maturaçăo inicial (O) dispostos ventralmente aos rins (R). Notar a presença de ovócitos em desenvolvimento diagnosticados macroscopicamente (seta). Escala em centímetros.

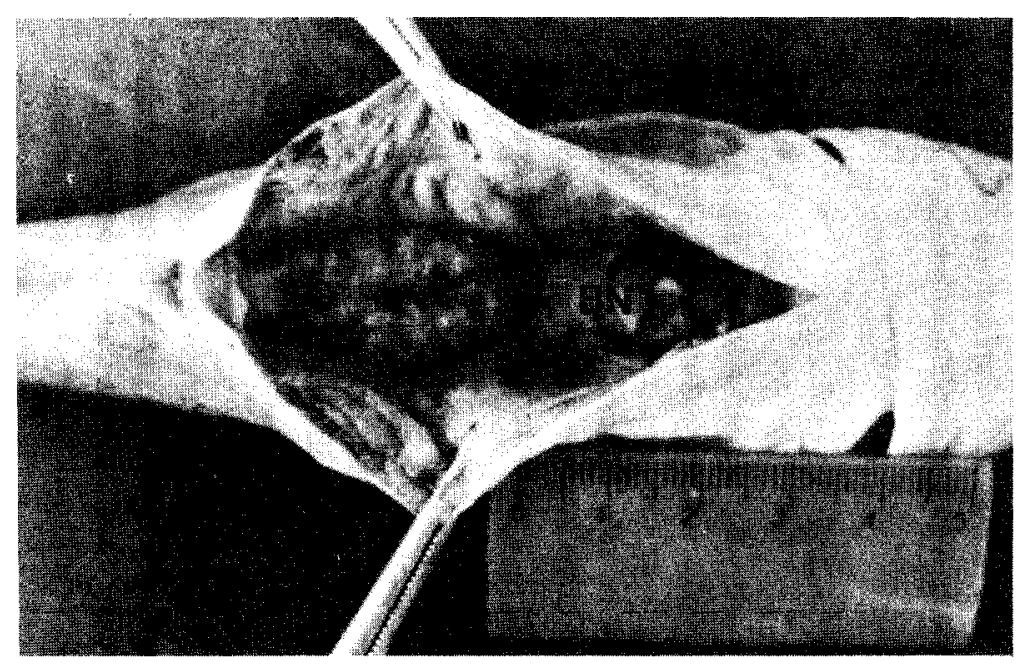

Fig. 19. Fêmea de $C$. spixii eviscerada com ovários parcialmente maduros $(\mathrm{O})$ dispostos ventralmente aos rins e bexiga natatória $(\mathrm{BN})$. Escala em centimetros. 
Diagnosticou-se a formação do folículo pósovulatório em um dos ovários analisados neste estádio, verificando-se a expulsão de um ovócito em maturação final pela aparente constrição das células foliculares e da teca (Tab. 1 e Fig. 10).

Estádio R (em recuperação): Nesta fase os ovários ocupam menos de metade do comprimento da cavidade corporal, possuem coloração rósea a marrom clara, apresentando inúmeras pontuações castanhas e sendo possível verificar macroscopicamente a formação de ovócitos em desenvolvimento (Fig. 23).

A nível microscópico esta fase é caracterizada pela presença de muitos nódulos fibrosos, resultantes do processo de absorção dos folículos pós-ovulatórios, agrupamentos muito frequentes de macrófagos contendo pigmentos hemossideróticos de coloração castanha (em colorações rotineiras como $\mathrm{HE}$ ), que correspondem as pontuaçres observadas macroscopicamente, ovogônias, ovócitos em estádio cromatina-nucleolar, ovócitos perinucleolares pouco frequientes, ovócitos cortical-alveolares muito frequentes e raros ovócitos atrésicos (Tab. 1).

\section{Discussão}

$\mathrm{O}$ aspecto macroscópico dos ovários de Cathorops spixii é semelhante ao descrito anteriormente por Tucker (1985) para Ictalurus punctatus, por Lima et al. (1991) para Piaractus mesopotamicus e por Reis (1986) para Netuma $b a r b a$, apresentando estrutura anatômica que permite classificá-lo no tipo "cistovariano" proposto por Hibiya (1982), uma vez que verifica-se a presença do lúmen ovariano contínuo com o oviduto.

Embora tenham sido realizados alguns trabalhos da biologia reprodutiva de arídeos, os quais utilizaram o diagnóstico microscópico de maturidade gonadal, neste trabalho foi possível observar particularidades sem descrição anterior na literatura especializada, relativas à estrutura das diferentes fases das células germinativas ovarianas, bem como da estrutura microscópica dos ovários, destacando-se as variações verificadas pelas células foliculares, úteis para o diagnóstico dos tipos germinativos ovarianos, devidas a alterações funcionais das mesmas; processos de regeneração verificados em ovários em recuperação; formação da membrana vitelina, observada em ovócitos em processo de vitelogênese, na qual, tardiamente constata-se a presença de estriação transversal marcante devida à presença de inúmeros microvilos, envolvidos no processo de vitelogênese.

A presença de uma ou duas camadas de células foliculares pavimentosas observadas em torno de alguns ovócitos perinucleolares tardios, mencionada anteriormente como fator de diagnóstico deste estádio de desenvolvimento ovocitário, parece ser uma estrutura transitória, onde o epitélio folicular deve tornar-se novamente monoestratificado à medida que o ovócito cresce. Tal evento é justificado por Guraya (1986) como uma condição de pseudoestratificação que reflete uma reserva celular a ser utilizada durante o crescimento rápido do ovócito, verificado também neste trabalho, aonde a variação de tamanho dos diferentes estádios de desenvolvimento dos ovócitos é considerável.

A vitelogênese em teleósteos, segundo Narahara (1991), tem componentes endógenos ou exógenos, de acordo com o local em que se inicia o processo de vitelogênese, podendo ocorrer apenas a vitelogênese endógena nos ovócitos em início de desenvolvimento, ou a ocorrência simultânea de vitelogênese endógena e exógena em ovócitos em estádios mais avançados de desenvolvimento.

A vitelogênese endógena ocorre em ovócitos vitelogênicos em início de desenvolvimento (corticalalveolares), enquanto que o predomínio da vitelogênese exogena sobre a endogena ocorre em ovócitos vitelogênicos propriamente ditos até o momento da ovulação (Narahara, op. cit., Tucker, 1985). A vitelogênese exógena parece ser a que mais contribui para o crescimento acentuado do ovócito que, nesta fase, começa a adquirir material por micropinocitose, através dos microvilos, formando os grânulos de vitelo que, à medida que vão migrando ao interior do ovoplasma, deslocam as vesículas precursoras dos alvéolos corticais para a periferia do ovócito (Monteros \& Labarta, 1987).

Nos ovócitos em estádio cortical-alveolar de Cathorops spixii provavelmente ocorra predominantemente vitelogênese endógena de vitelo, uma vez que até esta fase de desenvolvimento não se observou a presença dos microvilos, que otimizam o processo de vitelogênese exógena. Cabe citar que os alvéolos corticais, típicos desta fase das células germinativas ovarianas, são, às vezes, denominados erroneamente como vesículas de vitelo uma vez que, segundo West (1990), o conteúdo de tais alvéolos ou vesículas não terá função na nutrição do embrião, visto que, no momento da fertilização, o conteúdo destas estruturas é liberado no espaço perivitelínico entre a membrana vitelina e o protoplasma, visando impedir a polispermia. Portanto, a utilização do termo ovócito cortical-alveolar, proposto por West (op. cit.), é mais adequado do que o termo ovócito em vitelogênese lipídica, às vezes empregado para esta fase de desenvolvimento ovocitário, além de colaborar com a iniciativa do mesmo autor de padronizar a utilização de uma terminologia comum, o que facilitaria a comparação dos dados obtidos entre as diferentes espécies de peixes. 


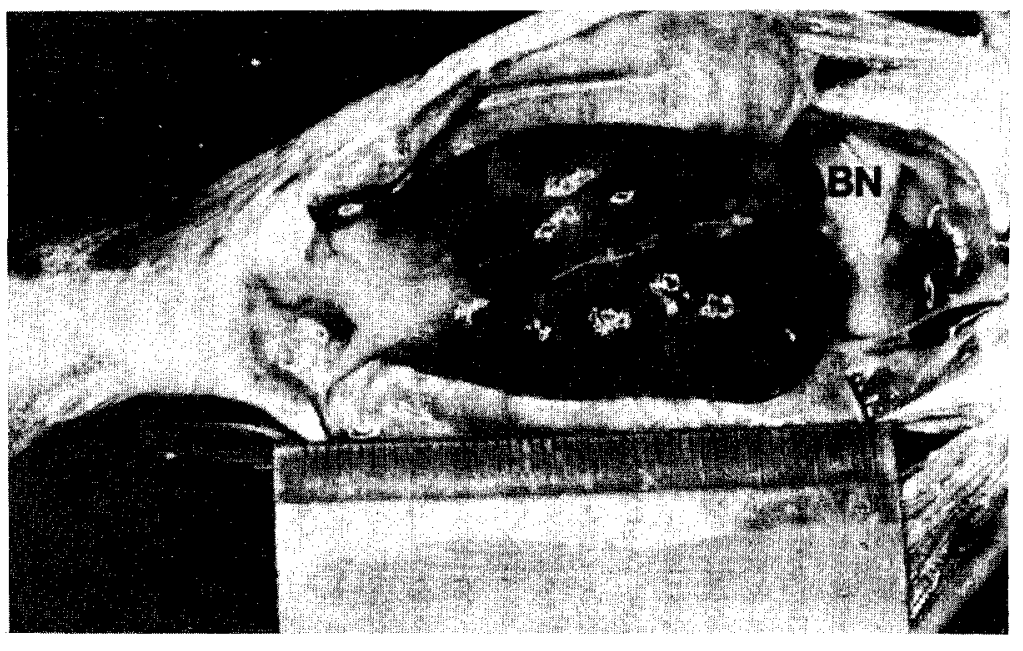

Fig. 20. Fêmea de $C$. spixii eviscerada com ovários maduros $(O)$ dispostos ventralmente aos rins e bexiga natatória $(\mathrm{BN})$. Notar a transparência da parede ovariana, que permite evidenciar a presença de ovócitos volumosos, contendo abundante quantidade de vitelo no seu interior. Escala em centímetros.

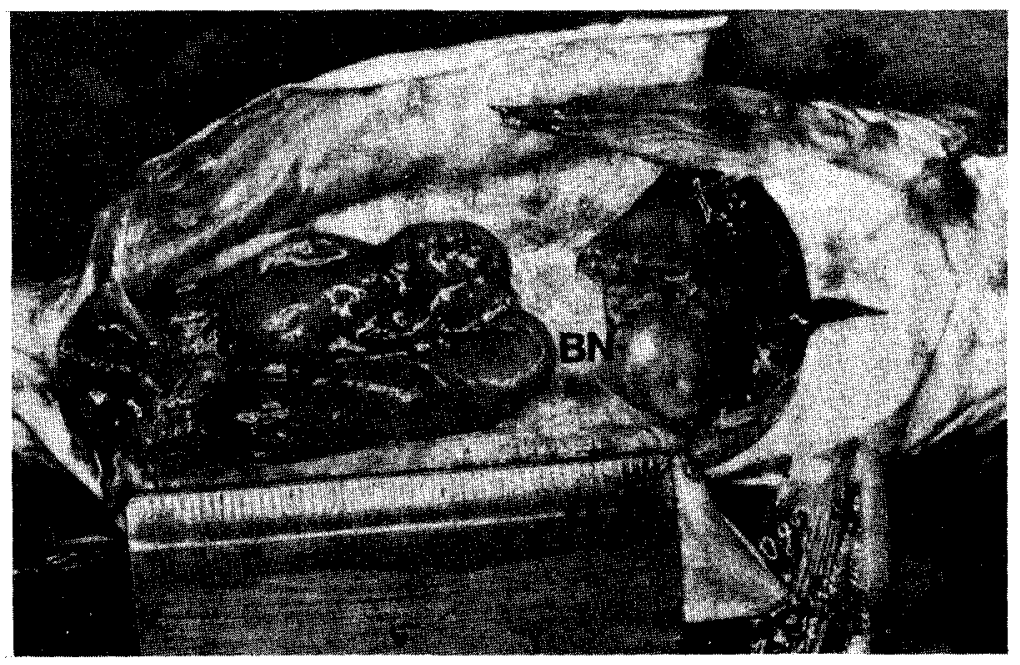

Fig. 22. Fêmea de C. spixii eviscerada com ovários desovados $(\mathrm{O})$ de aparência flácida $\mathrm{e}$ hemorrágica dispostos ventralmente aos rins e bexiga natatória (BN). Escala em centímetros.

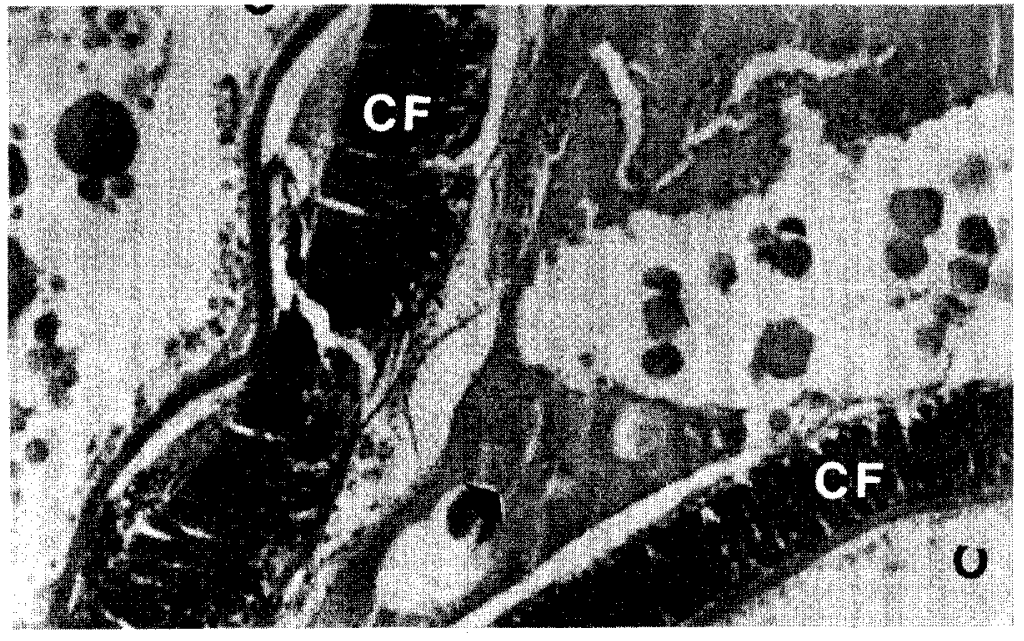

Fig. 21. Corte transversal de ovário de C. spixii. Oócitos em maturação final (O), notandose entre as células foliculares (CF) de ambos a presença de substância acelular (seta). PAS + Hematoxilina. 240X.

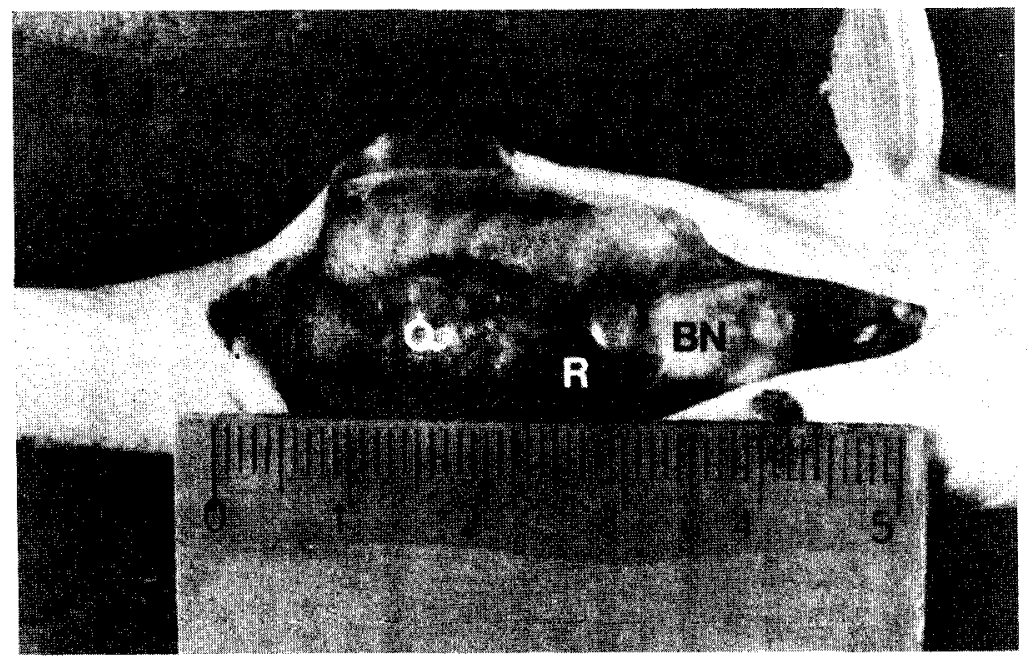

Fig. 23. Fêmea de C. spixii eviscerada com ovários em recuperação (O) dispostos ventralmente aos rins (R) e bexiga natatória (BN). Notar a presença de pontuaçães de coloração castanha nos ovários. Escala em centímetros. 
Tab. 1. Classificação dos estádios de maturidade ovarianos de acordo com a presença e freqüência de estruturas e dos tipos celulares germinativos ovarianos

\begin{tabular}{|c|c|c|c|c|c|c|c|c|c|c|c|c|c|c|c|}
\hline \multirow{2}{*}{$\begin{array}{l}\text { Estádios de } \\
\text { Maturidade }\end{array}$} & \multicolumn{15}{|c|}{ Estruturas e Tipos Celulares Germinativos Ovarianos } \\
\hline & Oog & $\mathrm{OCN}$ & $\mathrm{OPi}$ & $\overline{\mathrm{OPt}}$ & OCAi & OCAt & OVit & OMf & OAtr & FPO & $\mathrm{NF}$ & Mac & LO & Vascularizacão & Parede \\
\hline A & + & + & +++ & +++ & - & - & - & - & - & - & - & - & $++t$ & início & \\
\hline $\mathrm{Bi}$ & + & + & $H$ & + & $+1+$ & - & - & - & - & - & - & - & + & & \\
\hline Bf & + & + & +1 & $+H$ & $+t$ & $t+t$ & - & - & - & - & - & $H$ & - & & \\
\hline $\mathbf{C i}$ & + & + & $H$ & +1 & + & ++ & +++ & + & - & $\overline{-}$ & - & - & - & aumentada & \\
\hline$\overline{C f}$ & + & + & + & + & t & + & +1 & $+1+$ & - & - & $=$ & - & - & intensa & delgada \\
\hline$\overline{\mathrm{D}}$ & + & + & + & + & - & - & - & - & H & +++ & - & - & - & & \\
\hline$\overline{\mathbf{R}}$ & ++ & ++ & H & +4 & $+1+$ & +1 & - & - & + & - & +++ & H1 & - & & \\
\hline
\end{tabular}

(- Ausente; + Raro; + Pouco Freqüente; +1+ Muito Freqüente) (Oog - ovogônias, OCN - ovócito em estádio cromatina-nucleolar, OPi - ovócito em estádio perinucleolar inicial, OPt - ovócito em estádio perinucleolar tardio, OCAi - ovócito em estádio cortical-alveolar inicial, OCAt - ovócito em estádio cortical-alveolar tardio, OVit - ovócito vitelogênico propriamente dito, OMf - ovócito em maturação final, OAtr - ovócito atrésico, FPO folículo pós-ovulatório, nódulos fibrosos, Mac - macrófagos, LO - lamelas ovarianas e vascularização da parede ovariana).

As características de células em ativa síntese proteica das células foliculares dos ovócitos em maturação final e a vascularização da teca por nós relatados para Cathorops spixii evidenciam a ocorrência simultânea de vitelogênese respectivamente endógena e exógena, que ocorrem nesta fase, e corroboram a observação de ocorrência mais expressiva, entre ambas, da exógena, que explicaria o aumento acentuado do volume dos ovócitos neste estágio de desenvolvimento. A presença nos ovócitos em maturaçăo final de microvilos numerosos e relativamente grandes, que possuem função na absorção, no estádio Cf (caracterizado pela presença de ovócitos em maturação final) reforçam a observação acima proposta.

A presença de um único lote de ovócitos em maturação final resulta em desova total, confirmada pela ausência de ovócitos em maturação final residuais, bem como de qualquer outro ovócito em processo de vitelogênese em ovários desovados (Tab. 1). A presença da substância adesiva, visualizada macroscopicamente em ovários maduros, com coloração esbranquiçada e comprovada microscopicamente como uma substância acelular eosinófila e PAS positiva, parece ser produzida pelas células foliculares, e assim como verificado em outros arideos por Rimmer \& Merrick (1983), assume a função de manter os ovócitos desovados aderidos até o momento da fecundação destes pelo macho, contribuindo, deste modo, para a ocorrência da desova do lote único de ovócitos, e facilitando, deste modo, a fecundação dos mesmos pelos espermatozóides.

A presença de tal substância apenas em parte dos ovários maduros, com praticamente todos os ovócitos prontos a serem desovados aparentemente é devida à produção desta pouco antes do momento da desova, para garantir que o maior número possível de ovócitos maduros seja por ela envolvido, mantendo o lote único de ovócitos maduros aderidos para otimizar o processo de fecundação.

As evidências acima descritas, associadas à presença, em todos os estádios de desenvolvimento, de ovogôniás, ovócitos em estádio cromatinanucleolar e ovócitos perinucleolares (Tab. 1), que indicam que esta espécie desova periodicamente durante a sua vida, e que, a cada período apenas um lote de ovócitos é eliminado, permitem classificar o mecanismo de desenvolvimento ovocitário da espécie como "sincrônico em dois grupos" (Vázzolèr, 1996).

Cabe ressaltar que a utilização do termo "ovários parcialmente maduros" objetiva esclarecer que, apesar de conter alguns ovócitos em maturaçăo final, o ovário não está apto a desovar, já que os demais ovócitos, predominantemente vitelogênicos estão em processo final de maturação, e portanto inaptos para a fertilização. Também não foi encontrada, entre eles, a substância acelular adesiva, bem como não foi observada em nenhum ovário diagnosticado como totalmente maduro a presença de folículos pós-ovulatórios, ou mesmo a presença de ovócitos em maturação final em ovários diagnosticados como desovados, que poderiam caracterizar uma desova parcelada.

Embora deva ocorrer a presença da micrópila na membrana vitelina dos ovócitos em maturação final, envolvidos pela substância adesiva mencionada, não se verificou a presença de tal estrutura.

A presença das lamelas ovarianas, notada apenás nos ovários nos estádios iniciais de desenvolvimento, e que aumentam a superficie do revestimento interno do órgão, não foi notada nos ovários dos peixes que haviam se reproduzido ao menos uma vez, e que, passaram pelo estádio " $R$ " (em recuperação). Aparentemente tal ausência poderia ser compensada pela presença dos nódulos fibrosos, formados a partir do processo de absorção de folículos atrésicos e de corpos lúteos pós- 
ovulatórios, que promoveriam um aumento da superfície do revestimento interno do ovário.

Apesar da morfologia microscópica dos tipos germinativos ovarianos ser semelhante a dos descritos na literatura para telésteos, em Cathorops spixii nota-se a presença de estruturas que permitem diagnosticar um número maior de estádios de desenvolvimento ovocitário. Entre elas encontram-se as lamelas ovarianas, macrófagos, folículos pósovulatórios, células foliculares com variaçóes morfológicas decorrentes de alterações funcionais, entre estas variações destaca-se a presença de microvilos em número e tamanho nunca antes descritos, além da grande variação em tamanho e forma dos ovócitos, bem como de suas características citológicas (núcleo, nucléolos, corpo de Balbiani, basofilia ou acidofilia citoplasmática). Por isso foi possível classificar o desenvolvimento ovarianu em sete estádios, enquanto Mishima \& Tanji (1983), analisando o desenvolvimento ovariano através de características macroscópicas do grau de maturidade pela escala de Kubo \& Yoshinara (1972), diagnosticaram apenas quatro estádios.

A análise da ocorrência e freqüência relativa de estruturas e das fases de desenvolvimento das células germinativas ovarianas leva a crer que tais estádios sigam a escala descrita no ciclo de desenvolvimento do estado reprodutivo a seguir:

\begin{tabular}{rr|}
$\mathrm{A} \rightarrow \mathrm{Bi} \rightarrow \mathrm{Bf} \rightarrow \mathrm{Ci} \rightarrow \mathrm{Cf}$ \\
$\uparrow$ & $\downarrow$ \\
$\mathrm{R}$ & $\leftarrow \mathrm{D}$ \\
\hline
\end{tabular}

\section{Conclusões}

As variaçס̃es das características citológicas apresentadas pelos tipos celulares germinativos ovarianos em crescimento de Cathorops spixii permitiram a obtenção de seis diferentes fases de desenvolvimento ovocitário: ovogônia, ovócito em estádio cromatina-nucleolar, ovócito perinucleolar, ovócito cortical-alveolar, ovócito vitelogênico, ovócito em maturação final.

A estrutura dos ovários e as características das diferentes fases de desenvolvimento dos tipos celulares germinativos e das células foliculares presentes, revelados pela análise microscópica durante o seu desenvolvimento, permitem classificálo no tipo cistovariano, com uma escala de maturidade ovariana composta por sete estádios: imaturo (A), em maturação inicial (Bi), em maturação final $(\mathrm{Bf})$, parcialmente maduro (Ci), maduro (Cf), desovado (D) e em recuperação (R).
A presença de um lote único de ovócitos resulta em desova total e permite a classificação do desenvolvimento ovocitário da espécie como sincrônico em dois grupos.

\section{Referências bibliográficas}

Aguirre, A. 1939. Sistemática e aspectos biológicos de tainhas e bagres de maior valor econômico que frequientam as lagoas dos Patos e Mirim. Rev. Soc. Bras. Agron., 2(1):19-25.

Alexandrino, A. C.; Phan, M. T.; Pinheiro, E. F. G. 1985. Caracterização macroscópica e microscópica das gônadas do curimbatá, Prochilodus scrofa (Steindachner, 1881), durante o ciclo reprodutivo. Bolm Zool., Univ. S. Paulo, 9:159-175.

Amaral, M. L. de F. M. do; Santos, R. A. dos; Seckendorff, R. W. V. 1988. Espécies mais comercializadas na região sudeste $e$ respectivas artes e embarcações utilizadas nas capturas. Bol. Téc. Inst. Pesca, S Paulo, (6):131.

Cervigón, M. F. 1966. Los peces marinos de Venezuela. Estac. Invest. Mar. Margarita. Fund. La Salle Cienc. Nat. Caracas. $2 v$.

Figueiredo, J. L. de \& Menezes, N. A. 1978. Manual de peixes marinhos do sudeste do Brasil. II. Teleostei (1). São Paulo, MZ-USP. 110 p.

Guraya, S. S. 1986. The cell and molecular biology of fish oogenesis. New York, Karger. 223p.

Hibiya, T. 1982. An atlas of fish histology: normal and patological features. Tokyo, Kodansha Ltda. $147 \mathrm{p}$.

Kubo, I. \& Toshinara, T. 1972. Suisan siguen-gaku (study of fisheries resources). Tokyo, Kyoritsu. 482 p.

Lima, R. V. A.; Bernardino, G.; Val-Sella, M. V.; Fava de Moraes, F.; Schemy, R. A. \& Borella, M. I. 1991. Tecido germinativo ovariano e ciclo reprodutivo de pacus (Piaractus mesopotamicus Holmberg, 1887) mantidos em cativeiro. Bolm Téc. Cepta, 4(1):1-46. 
Mishima, M. \& Tanji, S. 1983. Maturação e desova dos bagres marinhos (Osteichthyes, Ariidae) do complexo estuarino lagunar de Cananéia $\left(25^{\circ} \mathrm{S}, 48^{\circ} \mathrm{W}\right)$. Bolm Inst. Pesca, S Paulo, 10:129-141.

Monteros, J. E. \& Labarta, U. 1987. Reproducción en Acuicultura. Madrid, Ind. Gráficas Espana. $321 \mathrm{p}$.

Narahara, M. Y. 1991. Histofisiologia do ovário de teleósteos. In: SEMANA SOBRE HISTOLOGIA DE PEIXES, 1. 1991. Palestras. Jaboticabal, UNESP/FUNEP. p.3946.

Peres-Rios, E. 1995. Aspectos reprodutivos de Prionotus punctatus (Bloch, 1797) (Teleostei: Triglidae) na região costeira de Ubatuba, São Paulo, Brasil. Dissertação de mestrado. Universidade de São Paulo, Instituto Oceanográfico. $62 \mathrm{p}$.

Reis, E. G. 1986. Reproduction and feeding habits of the marine catfish Netuma barba (Siluriformes, Ariidae) in the estuary of Lagoa dos Patos, Brasil. Atlântica, Rio Grande, 8: 35-55.
Rimmer, M. A. \& Merrick, J. R. 1983. A review of reproduction and development in the forktailed catfishes (Ariidae). Proc. Linn. Soc. N. S. W., 107(1):41-50.

Tucker, C. S. 1985. Channel catfish culture. New York, Elsevier. 657 p.

Vazzoler, A. E. A. de M. 1996. Biologia da reprodução de peixes teleósteos: teoria e prática. Maringá, Eduem. 169 p.

West, G. 1990. Methods of assessing ovarian development in fishes: a review. Aust. J. Mar. Freshwat. Res., 41(2):199-222.

Yáñez-Arancibia, A. \& Sanchez-Gil, P. 1988. Ecologia de los recursos demersales marinos: fundamentos em costas tropicales. México, AGT Editor. 228 p.

(Manuscrito recebido 09 abril 1997; revisado 11 fevereiro 1998; aceito 26 outubro 1998) 